\title{
SONOGRAPHIC FEATURES OF OVARIAN TUMORS IN PREGNANT WOMEN BEFORE SURGICAL INTERVENTION AND CHEMOTHERAPY
}

Gerasimova $A A^{1}$, Klimenko PA² $₫$

Center for Family Planning and Reproduction, Moscow, Russia

2 Pirogov Russian National Research Medical University, Moscow, Russia

\begin{abstract}
The problem of ovarian tumor differential diagnosis is solved using comprehensive ultrasound examination at different levels of efficiency. However, ultrasound imaging is an operator-dependent technique due to subjective interpretation of results. The study was aimed to assess the ultrasound signs of benign and malignant ovarian germ cell tumors (OGCTs) in pregnant women in order to determine the feasibility of surgical treatment and chemotherapy. The study was carried out using the logistic regression models. A group of 199 pregnant women with benign and malignant OGCTs were enrolled. Of them, 183 patients had benign, and nine patients had malignant tumors. In order to assess menstrual function and fertility, seven pregnant women were enrolled, who had previously received treatment for malignant OGCTs. Pre-operative assessment results were compared with morphological assessment data. Organ-preserving surgical treatment was performed (unilateral adnexectomy); if necessary, the patients received cisplatin-based chemotherapy. Perinatal outcomes were assessed. The median observation time between the malignant OGCT detection and the end of the study was 66 months (12-240 months). It was found that comprehensive ultrasound examination and logistic regression models (sensitivity 100\%, specificity 92.3\%, overall accuracy 92.8\%) enabled differential diagnosis of benign and malignant OGCTs. The number of unnecessary surgical procedures in patients with benign OGCTs was been limited, the pregnancy and childbirth outcomes were improved. Nine pregnant women received organ-preserving surgical treatment for malignant OGCTs, and three patients received chemotherapy after surgery, which allowed the patients to realize their reproductive potential.
\end{abstract}

Keywords: ultrasound examination, morphological assessment, ovarian tumors, pregnancy

Author contribution: the authors contributed to study management and manuscript writing equally, read and approved the final version of the article prior to publishing.

Compliance with ethical standards: the study was approved by the Ethics Committee of Pirogov Russian National Research Medical University (protocol № 176 dated June 25, 2018). The informed consent was submitted by all study participants.

$\triangle$ Correspondence should be addressed: Piotr A. Klimenko

Sevastopolsky prospect, 24a, Moscow, 117209; pa.klimenko@mail.ru

Received: 15.03.2021 Accepted: 14.04.2021 Published online: 28.04.2021

DOI: $10.24075 / \mathrm{brsmu} .2021 .018$

\section{УЗ-ПРИЗНАКИ ГЕРМИНОГЕННЫХ ОПУХОЛЕЙ ЯИЧНИКОВ У БЕРЕМЕННЫХ ПЕРЕД ХИРУРГИЧЕСКИМ ЛЕЧЕНИЕМ ИЛИ ХИМИОТЕРАПИЕЙ}

А. А. Герасимова 1 , П. А. Клименко $\bowtie$

1 Центр планирования семьи и репродукции, Москва, Россия

2 Российский национальный исследовательский медицинский университет имени Н. И. Пирогова, Москва, Россия

Проблему дифференциальной диагностики опухолей яичников решают с помощью комплексного ультразвукового исследования (УзИ), несмотря на то что оно является операторозависимым методом из-за субъективной интерпретации полученных данных. Целью исследования было оценить УЗ-признаки доброкачественных и злокачественных герминогенных опухолей яичников (ДГОЯ и ЗГОЯ) у беременных для определения возможности хирургического лечения и проведения химиотерапии (XT). Исследование проводили с помощью логрегрессионных моделей. В нем участвовали 199 беременных женщин с ДГОЯ и ЗГОЯ. Из них 183 пациентки имели доброкачественные опухоли, девять - злокачественные. Для оценки менструальной функции и фертильности в исследование были включены семь беременных после проведенного ранее лечения ЗГОя. Полученные на дооперационном этапе результаты обследования сопоставляли с морфологическими исследованиями. Выполняли хирургическое лечение в органосохраняющем объеме (одностороннюю аднексэктомию), при необходимости - ХТ на основе цисплатина. Изучали перинатальные исходы. Медиана наблюдения с момента выявления ЗГОЯ до окончания исследования составила 66 месяцев (12-240 месяцев). Обнаружено, что дифференцировать ДГОЯ со ЗГОЯ возможно с помощью комплексного УЗИ и логрегрессионных моделей (чувствительность метода - 100\%, специфичность - 92,3\%, суммарная точность - 92,8\%). Ограничено число нецелесообразных операций при ДГОЯ и улучшены исходы беременности, родов. Хирургическое лечение ЗГОЯ у девяти беременных выполнено в органосохраняющем объеме, у троих — с последующей ХТ, что позволило реализовать репродуктивный потенциал.

Ключевые слова: ультразвуковое исследование, морфологическое исследование, опухоли яичников, беременность

Вклад авторов: авторы внесли равнозначный вклад в проведение исследования и подготовку статьи, прочли и одобрили ее финальную версию перед публикацией.

Соблюдение этических стандартов: исследование одобрено этическим комитетом РНИМУ им. Н. И. Пирогова (протокол № 176 от 25 июня 2018 г). Все пациентки подписали добровольное информированное согласие на участие в исследовании.

$\triangle$ Для корреспонденции: Петр Афанасьевич Клименко Севастопольский проспект, д. 24а, г. Москва, 117209; pa.klimenko@mail.ru

Статья получена: 15.03.2021 Статья принята к печати: 14.04.2021 Опубликована онлайн: 28.04.2021

DOI: $10.24075 /$ vrgmu.2021.018

Differential diagnosis of ovarian tumors in pregnant women currently remains one of the unsolved problems in obstetrics. According to some authors, ovarian tumors and tumor-like formations are detected, on average, in $2-3 \%$ of pregnant women; the malignant ovarian tumors detection rate in pregnant women is 1 per $10,000-50,000$ patients [1-6].
Ovarian germ cell tumors (OGCTs) account for 20-30\% of all ovarian tumors; $2-5 \%$ of OGCTs are malignant $[7,8]$. The most common benign tumor is mature teratoma. The incidence of mature teratoma reaches $12 \%$ of all ovarian tumors. Rare teratomas include struma ovarii (1-2.7\% of all ovarian teratomas). According to literary sources, in 
5-20\% of cases struma ovarii can transform into carcinoma [9-12]. Malignant germ cell tumors (malignant OGCTs) are divided into two groups based on the clinical and histological features: dysgerminomas and non-dysgerminomas (yolk sac tumor, embryonal carcinoma, choriocarcinoma, immature teratoma, polyembryoma, and combinations of all listed types). Dysgerminomas account for up to $50 \%$ of all malignant OGCTs, this morphological type has more favorable prognosis compared to non-dysgerminoma [7, 13-16].

Currently, the problem of ovarian tumors differential diagnosis is solved using comprehensive ultrasound examination at different levels of efficiency. However, ultrasound imaging is an operator-dependent technique due to subjective interpretation of results. Therefore, to standardize the ultrasound imaging results, improve the ovarian tumor diagnosis accuracy and stratify the risk of malignant OGCT in order to determine the strategy of the further patients' management and treatment, the algorithms and complex predictive models have been constructed (RMI, IOTA (simple rules, LR1, LR2), ROMA, Kentucky morphology index (MI), O-RADS). According to ESGO guidelines (2017), in case of initial stage malignant OGCT detection, peritoneal surgical staging, and surgical removal of affected adnexa with preservation of contralateral ovary and pregnancy are recommended. However, biopsy of intact ovary and retroperitoneal lymph node dissection are considered non-viable options [17]. Cytoreductive surgery with maximum removal of tumor nodes and preservation of contralateral ovary without total lymphadenectomy is indicated to patients with advanced stage tumors. Chemotherapy is not recommended to patients with stage IA immature teratoma G1 or stage IA dysgerminoma. Chemotherapy is required in patients with advanced stage tumors. The platinum etoposide combination is considered the standard regimen (BEP or EP) $[6,18]$. Organ-preserving surgery makes it possible to preserve reproductive function and is in line with treatment concept for improved quality of life. In most cases, menstrual function is restored after chemotherapy, therefore, normal pregnancy might be expected [16, 19].

The study was aimed to assess the ultrasound signs of benign and malignant OGCTs in pregnant women in order to determine the feasibility of surgical treatment and chemotherapy.

\section{METHODS}

In 2000-2020 a study was carried out involving 199 patients with histologically verified OGCTs. Inclusion criteria: consent to participate in the study; pregnancy; ultrasound findings

Table 1. Distribution of pregnant women based of tumor morphology and stage confirming the pregravid or gravid ovarian tumor, subsequent surgical treatment and morphological verification of OGCT. Exclusion criteria: the pregnant woman's refuse to participate in the study; threatened miscarriage; intrauterine infection; defects in a fetus diagnosed before the study.

Ultrasonographic examination was performed with the Voluson E8 system (General Electric; USA) combined with transabdominal and transvaginal Doppler color flow mapping and pulse wave Doppler measurements. The tumor ultrasound features were assessed using the earlier proposed models [20].

In 192 pregnant women, the logistic regression models were used to assess the ultrasound signs of benign and malignant OGCTs, as well as to determine the feasibility of surgical treatment and chemotherapy. Of them, a group of 183 patients (95.3\%) had benign tumors: 180 patients had mature teratomas, and three patients had struma ovarii (Table 1). Among them, 32 patients (17.5\%) underwent surgery during pregnancy, 117 patients (63.9\%) received surgical treatment during a cesarean section, and 34 patients (18.6\%) received it postnatally: 11 patients (6\%) 3-5 days, and 23 patients (12.6\%) 3-6 months after giving birth. In most cases patients with small-sized benign OGCTs underwent resection of the ovaries, and patients with tumors larger than $10 \mathrm{~cm}$ in diameter underwent unilateral adnexectomy. In nine patients (4.7\%), malignant OGCTs were detected during progressive pregnancy. Seven patients $(77.8 \%)$ out of nine had stage I tumors, and two patients had stage III tumors. Pregnancy was preserved in all monitored patients. Six patients out of nine underwent surgery during different stages of gestation. Surgical treatment of three patients included the following procedures: cesarean section and adnexectomy with surgical staging. In four cases the tumor morphology was characteristic of pure dysgerminoma, and in one case the tumor was a combination of dysgerminoma with yolk sac tumor. Three pregnant women had immature teratomas, and one woman had a combination of immature teratoma with yolk sac tumor. Among nine patients with tumor process detected during pregnancy, three patients received drug treatment after surgery. Two patients received first-line BEP chemotherapy after giving birth because of stage III disease or yolk sac tumor, and one patient received two cycles of adjuvant carboplatin-based chemotherapy starting from the 18th week of gestation. In order to access menstrual function and fertility, medical records together with pregnancy and childbirth outcomes were studied in seven patients, who had received treatment for malignant OGCTs before pregnancy. Six out of seven patients have stage I tumors, and one patient had stage III tumor. All patients underwent organ-

\begin{tabular}{|c|c|c|c|}
\hline Morphological type & FIGO-TNM stage & Abs. & Total \\
\hline \multirow{4}{*}{ Dysgerminoma } & T1aNOMO/IA & 5 & \multirow{4}{*}{9} \\
\hline & $\mathrm{T} 1 \mathrm{bNOMO} / \mathrm{IB}$ & 1 & \\
\hline & T1cNOMO/IC & 2 & \\
\hline & T3N1M0/IIIC & 1 & \\
\hline Yolk sac tumor & T1cNOMO/IC & 1 & 1 \\
\hline \multirow{3}{*}{ Immature teratoma } & T1aNOMO/IA & 2 & \multirow{3}{*}{4} \\
\hline & T1cNOMO/IC & 1 & \\
\hline & T3cNOMO/IIIC & 1 & \\
\hline \multirow{2}{*}{ Mixed type germ cell tumor } & T1aNOMO/IA & 1 & \multirow{2}{*}{2} \\
\hline & T3N1M0/IIIC & 1 & \\
\hline Total & & 16 & 16 \\
\hline
\end{tabular}


Table 2. OGCT surgical treatment extent

\begin{tabular}{|c|c|c|c|}
\hline \multirow{2}{*}{ Surgical treatment extent } & \multirow{2}{*}{ Benign OGCTs } & \multicolumn{2}{|c|}{ Malignant OGCTs } \\
\hline & & Primary & Reintervention \\
\hline Resection of the ovary & 134 & 2 & \\
\hline Bilateral resection of the ovaries & 19 & & \\
\hline Biopsy of the second ovary + omentectomy & & & 1 \\
\hline Unilateral adnexectomy & 20 & 5 & \\
\hline Unilateral adnexectomy + resection of the second ovary & 10 & 1 & \\
\hline Unilateral adnexectomy + biopsy of the second ovary + omentectomy & & 3 & \\
\hline $\begin{array}{l}\text { Unilateral adnexectomy + resection of the second ovary + omentectomy + multiple peritoneal } \\
\text { biopsy }\end{array}$ & & 2 & \\
\hline $\begin{array}{l}\text { Unilateral adnexectomy + resection of the second ovary + omentectomy + multiple peritoneal } \\
\text { biopsy + retroperitoneal lymph node biopsy }\end{array}$ & & 2 & 2 \\
\hline $\begin{array}{l}\text { Unilateral adnexectomy + resection of the second ovary + omentectomy + multiple peritoneal } \\
\text { biopsy + retroperitoneal lymph node dissection }\end{array}$ & & 1 & 1 \\
\hline Retroperitoneal lymph node dissection, peritoneal tumor nodes removal & & & 1 \\
\hline
\end{tabular}

preserving surgical treatment (adnexectomy). In five cases, the tumor morphology was characteristic of pure dysgerminoma; one patient had immature teratoma, and another one had a yolk sac tumor. Six out of seven patients received BEP/E chemotherapy: one patient with immature teratoma G2, one patient with a yolk sac tumor, and four patients with IC stage or later stage dysgerminoma.

The surgical treatment extent in patients with malignant OGCTs was affected by each particular situation and by the urgent histological examination results (Table 2).

Histological examination was performed by standard methods. The morphological diagnoses were provided in accordance with the WHO Classification of Tumors of Female Reproductive Organs issued in 2014 [21].

Statistical analysis was carried out using the SPSS 15 software package (IBM; USA). The differences were considered significant when $p<0.05$.

\section{RESULTS}

The study showed that in pregnant women the scanograms of mature teratomas were characterized by polymorphous echographic pattern. In most cases mature teratomas were unilateral; bilateral lesion was identified in 29 patients (15.8\%). The tumor diameter varied significantly in the range of $0.5-15.0$ $\mathrm{cm}$, and the small-sized tumors $(0.5-3.0 \mathrm{~cm})$ were detected in 38 cases $(21 \%)$.

Based on the study results, in 75 cases (41\%), the ultrasound semiotics of benign OGCTs included mixed structure with predominant cystic component. In 49 patients (27\%), solid component prevailed over cystic component (cystic-solid structure). In 33 cases (18\%), neoplasms were represented by solid component with clearly visible capsule. The tumors were completely anechogenic (cystic variant) only in 26 cases (14\%).

The color and energy Doppler mapping revealed either single colored peripheral blood flow loci with resistance index (RI) of 0.4-0.6, or tumor avascularity. When assessing tumor

Table 3. Results and regression coefficients vascularization using color and energy Doppler mapping, blood flow with peripheral zones of vascularization was detected in 53 patients (29\%) with benign OGCTs.

The proposed logistic regression models for differential diagnosis of benign, borderline and malignant ovarian tumors in pregnant women possessed high reproducibility, sensitivity and specificity.

When diagnosing teratomas in pregnant women (Table 3) using the model, the accuracy exceeded $90 \%$, and the model sensitivity and specificity were $97 \%$ and $95 \%$, respectively (Fig. 1).

All tumors were characterized by mixed echogenicity.

Based on the study results, the ultrasound semiotics of malignant OGCTs was represented by solid masses found in 5 patients (55.6\%). Cystic and solid malignant OGCTs were detected in three cases (33.3\%), and the mixed structure with predominant cystic component was revealed in one case (11.1\%). In one case, the solid tumor component of higher echogenicity was represented by parenchymal papilla of more than $10 \mathrm{~cm}$ in diameter, and amounted to more than $80 \%$ of the total tumor volume. Hypervascularization was detected in $100 \%$ of cases. Ascitis was diagnosed in 3 patients (33.3\%).

The distinctive ultrasound signs of dysgerminoma were as follows: solid (lobulated) tumor, clear margins and rough external contour, medium-level echogenicity and multiple centrally located blood flow loci. In all cases, in scanograms of pregnant women, immature teratomas were represented by hypervascular cystic and solid masses. On the ultrasound scan the yolk sac tumor, $12 \mathrm{~cm}$ in diameter, was represented by a solid mass with multiple cystic cavities of various size, which contained suspension. Color Doppler mapping revealed multiple loci of blood flow with low RI values. In cases of mixed germ cell tumors (dysgerminoma + yolk sac tumor, immature teratoma + yolk sac tumor) the obtained ultrasound features and Doppler measures were consistent with ultrasound signs characteristic of malignant neoplasm in 100\% of patients (unclear, uneven contour, solid component amounting to 80-100\% of tumor volume, hypervascularization together with high values

\begin{tabular}{|c|c|c|c|c|}
\hline Histotype & Model accuracy & Area under the ROC curve & Parameters & Regression coefficients \\
\hline \multirow{3}{*}{ Mature teratoma } & \multirow{3}{*}{0.99} & \multirow{2}{*}{0.994} & Constant & -171.05 \\
\cline { 3 - 5 } & & & PI & 14.81 \\
\cline { 3 - 5 } & & & Localization & 14.65 \\
\cline { 3 - 5 } & & & Internal contours & 36.33 \\
\hline
\end{tabular}


of blood flow velocity and low values of Rl, presence of ascitis).

When constructing the model for differential diagnosis of benign, borderline and malignant ovarian tumors, the Spearman's rank correlation coefficients were calculated and included in the regression model for diagnosis of borderline and malignant ovarian tumors in pregnant women (Table 4).

When diagnosing borderline and malignant ovarian tumors in pregnant women, the model sensitivity was $100 \%$, the specificity was $92.3 \%$, and the overall accuracy was $92.8 \%$ (Fig. 2).

Surgical treatment of patients with benign and malignant OGCTs was performed after tumor detection (see Table 2). In the group of patients with benign OGCTs, who underwent surgery during different stages of gestation $(n=32)$, the emergencies in the first-second trimesters (adnexal torsion resulting from the tumor) were considered indications in four cases (12.5\%); tumor size and bilateral tumor in the second trimester determined the kind of surgical treatment in 28 cases (87.5\%). In 13 patients (11.1\%) the presence of neoplasm was considered an indication to surgery. The other 104 pregnant women (about 89\%) underwent surgery because of the combination of indications (uterine scar, placenta accreta, preeclampsia, breech presentation, hemolytic disease of the fetus, narrow pelvis, fetal malposition, and the presence of a tumor). In the group of 106 patients (90.5\%) with benign OGCTs the delivery was performed at term. Preterm operative vaginal delivery due to life-threatening birth defects, placental abruption, preeclampsia not amenable to therapy, and premature discharge of amniotic fluid was performed in 11 cases (9.4\%) between 25-35 weeks of gestation. All infants were born alive; the newborns' morphofunctional characteristics corresponded to their gestational age (full-term infants with Apgar score 7-9 weighted 2,500-4,150 g; premature infants with Apgar score 3-9 and Silverman Andersen respiratory severity score 3-5 weighted 650-2,850 g). Surgical treatment in the form of resection of the ovaries was performed postpartum in patients with small-sized tumors.

The median age of nine patients at the moment of malignant OGCT detection was 26 years (20; 32).

Three patients out of nine with malignant OGCTs received drug treatment. Two patients received BEP as first-line chemotherapy after delivery. In cases of stage IA dysgerminomas only surgical treatment was performed. Combined-modality therapy (surgery + chemotherapy) was used in patients with stage III immature teratomas (G2) and mixed germ cell tumors (stages I and III). It should be noted that one of these patients received two cycles of adjuvant carboplatin-based chemotherapy during pregnancy, starting from the 18th week. The mixed ovarian germ cell tumor (combination of immature teratoma with yolk sac tumor) was diagnosed at 12-13 weeks of gestation; surgery was performed 2 days later. Surgical treatment included unilateral adnexectomy, biopsy of the contralateral ovary, omentectomy, multiple peritoneal biopsy,

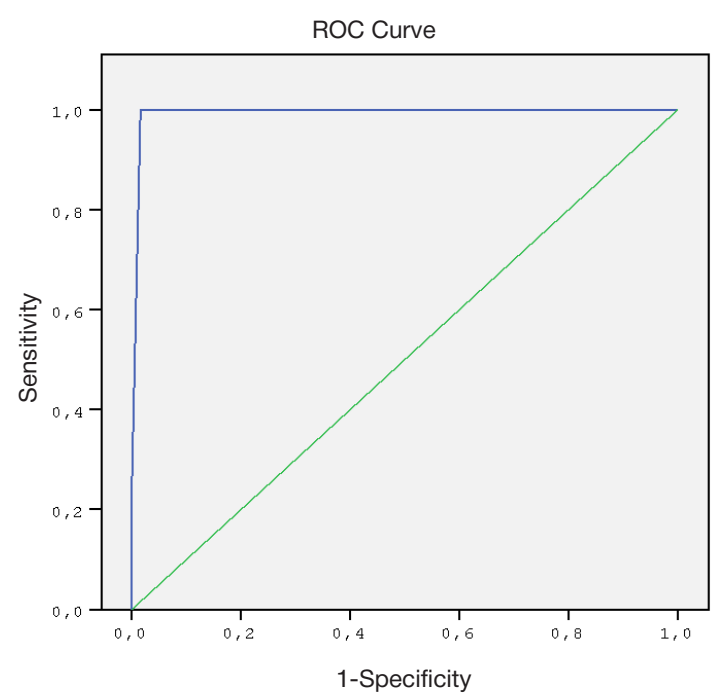

Fig. 1. ROC curve for the model of mature teratoma identification and peritoneal washing.

No fetal injury was detected after the combined-modality therapy. This full-term pregnancy ended in second livebirth. The full-term newborn girl weighted $3,850 \mathrm{~g}$, and was $55 \mathrm{~cm}$ long. She was assigned the Apgar score 8-9. The patient is under observation with no signs of disease progression. The child grows and develops normally, matching her age.

Recurrent tumor was detected in one patient, who had previously undergone surgery because of malignant OGCT at 25 weeks of gestation. Surgical treatment included unilateral adnexectomy; histologic diagnosis of mixed germ cell tumor (combination of dysgerminoma with yolk sac tumor) was established. Preterm labor occurred at 30 weeks of gestation: the preterm cesarean section was performed together with surgical removal of anterior abdominal wall tumor and ovarian ligament stump, resection of the contralateral ovary, omentectomy, paracolic gutters biopsy, surgical removal of paraaortic lymph node (based on the histological assessment results, the mixed germ cell tumor with predominant yolk sac tumor structures was diagnosed). The newborn boy weighed $1420 \mathrm{~g}$ and was $40 \mathrm{~cm}$ long. He was assigned Apgar score 6, and Silverman Andersen respiratory severity score 4.

Among nine pregnant women with malignant OGCTs detected during pregnancy, six women (66.6\%) underwent cesarean section (four women because of tumors, one woman because of postterm pregnancy, and one woman because of preterm labor); three patients (33.3\%) delivered per vias naturalis.

The median observation time in patients with malignant OGCTs was 66 months (12-240 months), one patient with stage III mixed germ cell tumor (combination of dysgerminoma and yolk sac tumor) died.

The further combined-modality therapy (surgery +

Table 4. Spearman's rank correlation coefficients included in the regression model for diagnosis of borderline and malignant ovarian tumors in pregnant women

\begin{tabular}{|c|c|c|c|c|}
\hline \multirow{2}{*}{ Predictor variable } & Ovarian tissue & $\mathrm{RI}$ & $\mathrm{Pl}$ & Localization of blood vessels \\
\hline Ovarian tissue & - & - & - & - \\
\hline \multirow{2}{*}{$\mathrm{RI}$} & $r=-0.145$ & - & - & - \\
\cline { 2 - 5 } & $p=0.01$ & & & \\
\hline \multirow{2}{*}{$\mathrm{PI}$} & $r=0.326$ & $r=0.097$ & - & - \\
\cline { 2 - 5 } & $p=0.046$ & $r=0.01$ & $r=0.294$ & \\
\hline \multirow{2}{*}{ Localization of blood vessels } & $r=0.059$ & $p=0.01$ & $p=0.01$ & - \\
\cline { 2 - 5 } & $p=0.01$ & & & \\
\hline
\end{tabular}


chemotherapy) outcome monitoring in six out of seven patients with malignant OGCTs, who had received treatment before pregnancy, revealed no menstrual function disorders. The median time between the end of chemotherapy and the end of the study was 150 months (48-216 months). The first pregnancy occurred in 1-3 years (two patients), 4-6 years (two patients), and 7-10 years (one patient) after chemotherapy. Only one patient became pregnant after 12 years with the help of IVF. A total of 11 pregnancies occurred after the malignant OGCT treatment. All pregnancies ended in birth of healthy babies. During the follow-up period four patients became pregnant and delivered second time. No pregnancy and labor complications were observed in these patients.

In five patients (71\%), who had received treatment for malignant OGCTs before pregnancy, spontaneous labor at term was observed. In two cases (29\%) cesarean section was performed because of uterine scar and macrosomic postterm delivery. The newborns' condition matched their gestational age, they were assigned Apgar score 8-9.

\section{DISCUSSION}

OGCTs account for $20-30 \%$ of ovarian tumors. According to literary sources, these tumors are characterized by the greatest structural diversity. Mature teratomas account for $12 \%$ of all ovarian tumors and for up to $97 \%$ of all OGCTs [8, 22-24]. Seven types of benign and several types of malignant neoplasms have been reported [22]. In 2005, three major types of ultrasound mature teratoma appearance were distinguished: cystic type (47-60\%), predominance of solid component (20-43\%), and mixed structure (9-20\%) [24]. A rare type of teratoma is struma ovarii, which accounts for $1-2.7 \%$ of all ovarian teratomas. In $75 \%$ of cases, ovarian strumae have a specific feature: the spongy texture area of medium-level echogenicity with single hyperechoic inclusions inside the tumor [23].

There is evidence that the ultrasound imaging sensitivity when examining teratomas is $92.3 \%$, and the method specificity is $99.4 \%$; when diagnosing borderline and malignant ovarian tumors in pregnant women, sensitivity and specificity are 88.9 and $98.2 \%$ respectively [25]. In our study, with the use of contemporary ultrasound imaging techniques for differential diagnosis of OGCTs, we managed to establish the correct diagnosis during the pre-operative assessment of patients in almost all cases despite the tumor structure variability. It can be concluded that tumors with increased risk of malignant transformation are characterized by solid or mixed structure with predominant solid component, as well as by hypervascularization.

Ovarian tumors contribute to pregnancy complications, as well as to high maternal and fetal morbidity. The most common obstetric complication is miscarriage (its frequency is $30-75 \%)$; miscarriage may result from underlying process, surgical treatment and chemotherapy [26-28]. According to literary sources, the incidence of ovarian tumor torsion is $6-9 \%$, the incidence of tumor capsule rupture is $12-14.7 \%$, and the incidence of birth canal obstructed by the tumor is $14-21 \%$ [25]. In our study, the threatened miscarriage rate was $18.2 \%$, adnexal torsion was detected in $2.1 \%$ of patients, hematoma with abscess formation was a complication of one pregnancy, and the birth canal obstruction rate reached 8.9\%. Two pregnancies ended in preterm labor 3 and 5 weeks after surgical treatment of malignant OGCTs.

Unilateral adnexectomy is the optimal primary surgical treatment regardless of the tumor stage. According to world's literature, in case of malignant OGCT diagnosed during

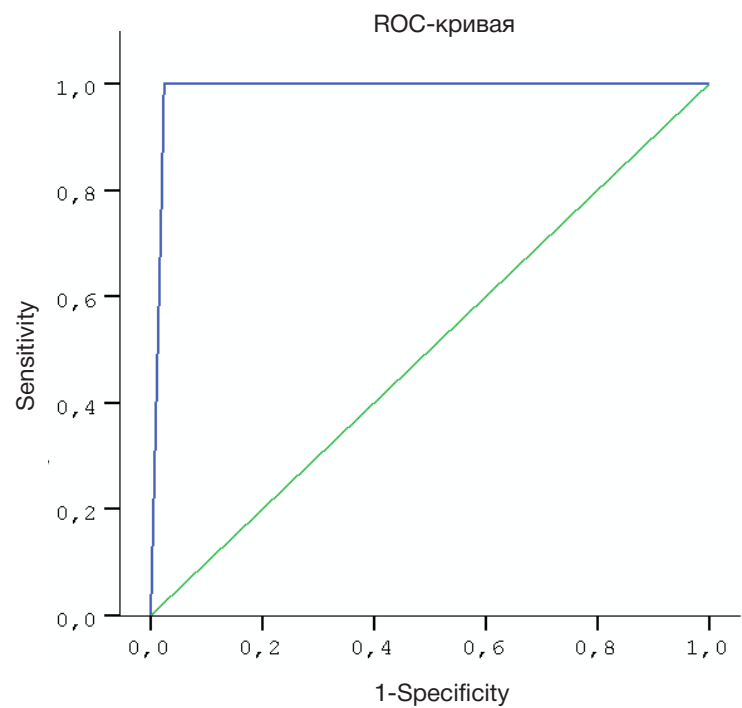

Fig. 2. ROC curve for the model of borderline and malignant ovarian tumor diagnosis in pregnant women

pregnancy, the treatment tactics are focused on prolongation of pregnancy with combined-modality therapy: surgery in the second trimester with subsequent chemotherapy or follow-up $[4,16,29]$. During our study, pregnancy was preserved in all patients, and all surgical procedures were organ-preserving (unilateral adnexectomy), which was in line with international guidelines. In a number of studies, 10 pregnant patients were monitored. Four pregnancies ended in abortions; six patients underwent adnexectomy at different stages of gestation [16, 30]. Currently, owing to high sensitivity of malignant OGCTs to chemotherapy, as well as to possibility to cure up to $80 \%$ of patients even with advanced stage tumors, the surgical intervention extent has become possible allowing us to preserve the patient's reproductive function [16]. According to literature, chemotherapy is not indicated to patients with malignant OGCTs after surgery in case of stage IA immature teratoma Gl or stage IA dysgerminoma. Chemotherapy is indicated to patients with advanced stage tumors. BEP or EP is the standard chemotherapy regimen. Three out of nine pregnant women with malignant OGCTs received BEP chemotherapy as firstline therapy after surgery: two patients received chemotherapy after giving birth, and one patient received it during pregnancy, starting from the 18th week of gestation (two cycles of adjuvant carboplatin-based chemotherapy).

It can be assumed that the most aggressive malignant neoplasms are found during pregnancy. Therefore, in case of stage II-III non-dysgerminoma detection during pregnancy, chemotherapy should be prescribed after primary surgical treatment and the implantation and organogenesis completion, without waiting for the baby to be born. Exposure to bleomycin, etoposide and cisplatin in the second and third trimesters is safe for the fetus [4]. In patients with malignant OGCTs who had received pregravid organ-preserving surgery and drug treatment, pregnancies occurred and progressed, and healthy babies were born. In patients with benign OGCTs, the absence of ultrasound signs of malignant transformation made it possible to avoid surgery and related perinatal complications during pregnancy, and to perform surgical treatment of tumors postpartum.

\section{CONCLUSIONS}

Comprehensive diagnosis of OGCTs, which comprised determining the ultrasound criteria of malignancy, made it 
possible to provide rational management of pregnancy and childbirth, surgical treatment and chemotherapy of malignant
OGCTs, as well as to preserve patients' health and reproductive function.

\section{References}

1. Bahidze EV. Opuholi jaichnika u beremennyh. Zhurnal akusherstva i zhenskih boleznej. 2011; 3: 190-6.

2. Urmancheeva AF. Ginekologicheskij rak v sochetanii $s$ beremennost'ju. Prakticheskaja onkologija. 2009; 10 (4): 192-7.

3. Behtash N, Karimi Zarchi M, Modares Gilani M, et al. Ovarian carcinoma associated with precnancy a clinicopathologic analysis of 23 cases and review of the literature. BMC Pregnancy Childbirth. 2008; 8: 3.

4. Kwon YS, Mok JE, Lim KT, et al. Ovarian cancer during Pregnancy, Clinical and Pregnancy Outcome. J Korean Med Sci. 2010; 25 (2): 230-4.

5. Marret $\mathrm{H}$, Lhomme $\mathrm{C}$, Lecuru $\mathrm{F}$, et al. Guidelines for the management of ovarian cancer during pregnancy. Eur $\mathrm{J}$ Obstet Gynecol Reprod Biol. 2010; 149: 18-21.

6. Zagouri F, Dimitrakakis C, Marinopoulos S, et al. Cancer in pregnancy disentangling treatment modalitities. ESMO Open. 2016; 1 (3): e000016.

7. Chekini DA, Tryakin AA, Fedyanin MYu, Tyulyandin SA. Zlokachestvennye germinogennye opuholi jaichnikov: jepidemiologija, klinika, diagnostika, lechenie. Vestnik FGBU «RONC im. N. N. Blohina». 2016; 27 (2): 39-46.

8. Solopova AE, Sologub YuN, Solopova AG, Makacariya AD. Germinogennye opuholi jaichnikov - sovremennyj vzgljad na problemu. Zhurnal akusherstva i zhenskih boleznej. 2016; 65 (2): 4-15.

9. Choudhary S, Fasih N, Mc Innes M, Marginean C. Imaging of ovarian teratomas: appearances and complications. J Med Imaging Radiat Oncol. 2009; 53 (5): 480.

10. Yucesoy G, Cakiroglu Y, Muezzinoglu B, Besnili B, Yucesoy I. Malignant struma ovarii: a case report. $J$ of Korean Medical Science. 2010; 25 (2): 327-9.

11. Ognerubov NA, Ulitina ED. Struma jaichnika: sluchaj iz praktiki. Vestnik Tomskogo gosudarstvennogo universiteta. 2013; 18 (5): 2855-9.

12. Antonova IB, Fomin DK, Babaeva NA, i dr. Zlokachestvennaja struma jaichnika. Obzor literatury i sobstvennoe nabljudenie redkogo varianta opuholi. Trudnyj pacient. 2018; 16: 8-9.

13. Tyulyandin SA. Germinogennye opuholi jaichnikov. Prakticheskaja onkologija. 2006; 7 (1): 52-61.

14. Tyulyandin SA, Kerzhkovskaja NS, Strelcova ON. Germinogennye i granulezokletochnye opuholi jaichnikov. Prakticheskaja onkologija. 2009; 10 (2): 111-6.

15. Davydova IYu, Kuznecov VV, Karseladze Al, i dr. Organosohranjajushhie operacii $v$ lechenii nezreloj teratomy jaichnika. Opuholi zhenskoj reproduktivnoj sistemy. 2009; 1 (2): 81-85.

16. Chekini DA. Faktory prognoza i taktika lechenija bol'nyh zlokachestvennymi germinogennymi opuholjami jaichnikov

\section{Литература}

1. Бахидзе Е. В. Опухоли яичника у беременных. Журнал акушерства и женских болезней. 2011; 3: 190-6.

2. Урманчеева А. Ф. Гинекологический рак в сочетании с беременностью. Практическая онкология. 2009; 10 (4): 192-7.

3. Behtash N, Karimi Zarchi M, Modares Gilani M, et al. Ovarian carcinoma associated with precnancy a clinicopathologic analysis of 23 cases and review of the literature. BMC Pregnancy Childbirth. 2008; 8: 3.

4. Kwon YS, Mok JE, Lim KT, et al. Ovarian cancer during Pregnancy, Clinical and Pregnancy Outcome. J Korean Med Sci. 2010; 25 (2): 230-4.

5. Marret $\mathrm{H}$, Lhomme $\mathrm{C}$, Lecuru $\mathrm{F}$, et al. Guidelines for the

management of ovarian cancer during pregnancy. Eur $\mathrm{J}$ Obstet Gynecol Reprod Biol. 2010; 149: 18-21.

6. Zagouri F, Dimitrakakis C, Marinopoulos S, et al. Cancer in pregnancy disentangling treatment modalitities. ESMO Open. 2016; 1 (3): e000016.

7. Чекини Д. А., Трякин А. А., Федянин М. Ю., Тюляндин С.А. Злокачественные герминогенные опухоли яичников: эпидемиология, клиника, диагностика, лечение. Вестник ФГБУ «РОНЦ им. Н. Н. Блохина». 2016; 27 (2): 39-46.

8. Солопова А. Е, Сологуб Ю. Н., Солопова А. Г., Макацария А. Д. Герминогенные опухоли яичников - современный взгляд на проблему. Журнал акушерства и женских болезней. 2016; 65 
(2): 4-15.

9. Choudhary S, Fasih N, Mc Innes M, Marginean C. Imaging of ovarian teratomas: appearances and complications. J Med Imaging Radiat Oncol. 2009; 53 (5): 480.

10. Yucesoy G, Cakiroglu Y, Muezzinoglu B, Besnili B, Yucesoy I. Malignant struma ovarii: a case report. J of Korean Medical Science. 2010; 25 (2): 327-9.

11. Огнерубов Н. А., Улитина Е. Д. Струма яичника: случай из практики. Вестник Томского государственного университета. 2013; 18 (5): 2855-9.

12. Антонова И. Б., Фомин Д. К., Бабаева Н. А. и др. Злокачественная струма яичника. Обзор литературы и собственное наблюдение редкого варианта опухоли. Трудный пациент. 2018; 16: 8-9.

13. Тюляндин С. А. Герминогенные опухоли яичников. Практическая онкология. 2006; 7 (1): 52-61.

14. Тюляндин С. А., Кержковская Н. С., Стрельцова О. Н. Герминогенные и гранулезоклеточные опухоли яичников. Практическая онкология. 2009; 10 (2): 111-6.

15. Давыдова И. Ю., Кузнецов В. В., Карселадзе А. И. и др. Органосохраняющие операции в лечении незрелой тератомы яичника. Опухоли женской репродуктивной системы. 2009; 1 (2): 81-85.

16. Чекини Д. А. Факторы прогноза и тактика лечения больных злокачественными герминогенными опухолями яичников [диссертация]. М., 2017.

17. Диагностика и лечение доброкачественных новообразований яичников с позиции профилактики рака. Клинические рекомендации (протокол лечения). М., 2018; 51 с.

18. Amant F, Halaska MJ, Fumagalli M, et al. ESGO task force 'Cancer in Pregnancy'. Gynecologic cancers in pregnancy: guidelines of a second international consensus meeting. Int J Gynecol Cancer. 2014; 24 (3): 394-403.

19. Gershenson DM, Miller AM, Champion VL, et al. Reproductive and sexual function after platinum-based chemotherapy in longterm ovarian germ cell tumor survivors: a gynecologic oncology group study. J Clin Oncol. 2007; 25: 2792-7.

20. Герасимова А. А., Гус А. И., Клименко П. А., авторы;
Герасимова А. А., Гус А. И., Клименко П. А., патентообладатель. Способ дифференциальной диагностики опухолевидных образований и опухолей яичников у беременных. Патент на изобретение № 2325118. 05.06.2007

21. Kurman RJ, Carcangiu ML, Herrington CS, Young RH. World Health Organization classification of tumours of female reproductive organs. Lyon: IARC Press, 2014.

22. Стрижаков А. Н., Давыдов А. И. Клиническая трансвагинальная эхография. М., 1994; 183 с.

23. Демидов В. Н., Гус А. И., Адамян Л. В. Эхография органов малого таза у женщин. Кисты придатков матки и доброкачественые опухоли яичников: практическое пособие. М.: PAH, 2006; $100 \mathrm{c}$.

24. Озерская И. А., Агеева М. И. Ультразвуковая диагностика опухолей яичников. Ультразвуковая и функциональная диагностика. 2005; 4: 111-27.

25. Мартынов С. А., Жорданиа К. И., Адамян Л.В., Данилов А. Ю. Особенности диагностики и хирургического лечения беременных с опухолями и опухолевидными образованиями яичников. Онкогинекология. 2014; 2: 27-32.

26. Fauvet $\mathrm{R}$, Brzakowski $\mathrm{M}$, Morice $\mathrm{P}$, et al. Borderline ovarian tumors diagnosed during pregnancy exhibit a high incidence of aggressive features: results of a French multicenter study. Ann Oncol. 2012; 23 (6): 1481-7.

27. Blake EA, Kodama M, Yunokawa $M$, et al. Feto-materna outcomes of pregnancy complicated by epithelian ovarian cancer: a systematic review of literature. Eur J Obstet Gynecol Reprod Biol. 2015; 186: 97-105.

28. Lu D, Ludvigsson JF, Smedby KE, et al. Maternal cancer during pregnancy and risks of stillbirth and infant mortality. J Clin Oncol. 2017; 35 (14): 1522-9.

29. Giuntoli RL, Vang RS, Bristow RE. Evaluation and management of adnexal masses during pregnancy. Clin Obstet Gynecol. 2006; 49 (3): 492-505

30. Чекини Д. А., Трякин А. А., Федянин М. Ю. идр. Репродуктивная функция пациенток со злокачественными герминогенными опухолями яичников. Злокачественные опухоли. 2017; 7 (2): 47-53. 